\title{
SOME ISSUES OF MONGOLIA'S TRANSITION TO A MARKET ECONOMY
}

\section{Ts. Tsolmon}

Over the past four years, many important steps have been taken to restructure all spheres of public life in Mongolia. The adoption of the new Constitution which reflects the main structural issues of a democratic state, legally ratified this historic process.

Specifically, Mongolia has taken measures to privatize state and cooperative properties, change the tax and banking systems, liberalize prices and tariffs, establish floating exchange rates, and create new relations for the organization and production of economic units. Many practical steps have been taken to set up a legal basis for the transfer to a market economy. Favorable conditions for carrying out an open economic policy are being created in the country, which in-clude common principles of international legality. I would also like to stress that the measures facilitating Mongolia's transition to a market economy are being taken according to an agreement with the International Monetary Fund.

Given the need to change legislation to suit a market economy, the most important laws and acts relating to economic units, privatization, taxes, customs, and banking have been adopted. This has been very important in creating the legal basis for shaping the new economic environment. Although these laws and acts still need perfecting, they already have created new economic and social relations.

While there have been some initial achievements in the country's economy, it is still too early to say for certain that the country is on its way toward overall recovery and growth. Here are some details of the most recent developments.

\section{Monetary Policy}

After rapidly expanding in the first half of 1993, key monetary aggregates have settled into a slower growth pattern in recent months. According to figures released by the government, $\mathrm{M} 2$ grew $83.5 \%$ in the first half of the year and then slowed to $37.7 \%$ from June 30 to November 30, 1993. This trend parallels a slowdown in the rate of inflation.

The total loans outstanding in the banking system, a key indicator of the Central Bank's control over money creation, has fluctuated drastically in recent 
months. This reflects both weaknesses in the commercial bank sector, and an underlying instability in the lending process. All countries changing from a planned to a market economy experience similar difficulties in handling demands for preferential BA ik credits to industrial enterprises, farms and projects which can no longer receive large state subsidies. Such loans can lead to inflationary pressures or, when governments maintain an overall cap on lending in order to control inflation, as is being done in Mongolia, they can squeeze out credits to other sectors with more favorable fundamental economic conditions and prospects.

The banking system was restructured according to the new Law on Banking, and a two-tier banking system, comprising the Central Bank and commercial banks, has been established. With prices and tariffs now liberalized, particular attention needs to be paid to flexible monetary and credit policies in order to avoid inflation and to improve coordination of activities of the government and the Central Bank.

\section{Fiscal Policy}

Government budget figures for the first eleven months of 1993 show an overall deficit of 5.88 billion turgid, caused mainly by a major shortfall in customs and import sales tax revenues which, in turn, was due to a decline in imports. The government managed to keep the increase in its total wage bill below the inflation rate, and to make further progress in eliminating the many subsidies which formerly accounted for as much as $25 \%$ of total expenditures.

As usual, the central budget has been running a small surplus, but subsidies to local govcrments sent the consolidated budget numbers into the red. The government seems likely to meet its goal for 1994 of holding current expediters down to the level of total revenues. This will generate a small current surplus to be used in investment although most government investment is still financed by external aid.

\section{Liberalization of Prices}

Liberalization of prices has been one of the most complicated problems and has deeply affected the Mongolian people. The Stale Statistical Office bulletin shows that the consumer price index (CPI) rose 5.3\% in October 1993. Bringing the total increase for the first eleven months of the year to $176.1 \%$. Although still unacceptable, high, this represents a marked slowdown in infla- 
tion, particularly when we note that most price increases in 1993 took place at the beginning of the year. Over the eight months from March 31 through November 30,1993 , the CPI rose $82.4 \%$, compared with $153.6 \%$ during the same period in 1992. This trend is all the more encouraging because it has occurred at the same time that a number of key prices, including petroleum products, beef, mutton, and bread, as well as the tugrig /dollar exchange rate, have been quite moderate. Recent price increases have been primarily in the food sector, particularly in milk, flour products, and vegetables, and reflect both seasonal factors and earlier increases in the price of imported petroleum passed on to the agricultural sector.

\section{Exchange Rate}

Since the creation of a uniform floating exchange rate at the end of May 12, 20061993, the turgid has displayed impressive strength against the dollar in both the bank and parallel exchange markets. As of early April 1994 the official Mongol Bank exchange rate was 409 Tigris to the dollar, representing an appreciation of the turgid over a six-month period. Although some observers have attributed the Mongolian currency's recent strength to seasonal factors which have often led to its appreciation in the parallel market during the tourist season, the persistence of its strength into early 1994 is clear evidence that more fundamental factors are at work.

\section{Foreign Economic Relations}

The scope of Mongolia's foreign economic relations has been greatly expanded and its economy is now less dependent on only one country and one trading bloc. Mongolia has established relations with highly developed countries, including the United States, the European Community, and Asian market economies, and has opened the way for Mongolian businesses to the markets in those countries. Definite steps have been taken to liberalize foreign trade, and every Mongolian company is now legally free to trade and cooperate with foreign partners.

Attention has been paid to supporting foreign investments in Mongolia and to creating conditions for such investments. As a result of information released on the possibilities of direct investment, many foreign investors have come to Mongolia to learn more about its resources. 
Mongolia's foreign trade turnover through December 1993 totaled US \$ 654.6 million, $4.3 \%$ loner than the same period in 1992. This was entirely due to a $139 \%$ drop in imports to US $\$ 330.2$ million, caused by delays in the disbursement and utilization of some foreign aid projects. Exports for the first eleven months of 1993 were US\$ 324.4 million. There is considerable evidence, however, that official trade statistics fail to include the rapidly growing informal sector where hard currency earnings are an important potential source of private sector investment in the near future.

\section{Industrial Output}

Official industrial statistics for the first eleven months of 1993 report a $21.4 \%$ drop in industrial output compared with the same period in 1992. This figure, however, may include only declining older industrial enterprises from whom the government finds it relatively easy to gather information, and may leave out the new smaller businesses which are not reporting their output. The State Statistical Office is now revising its information-gathering procedures in order to better meet Mongolia's new economic conditions.

At the same time, the indisputable decline in output by many industrial enterprises is a source of concern, as these units provide the bulk of industrial employment in Mongolia. They may have to close down and lay off their workers if this trend is not reversed. Some of these older enterprises were dependent on trade with their former socialist partners, from whom they obtained key inputs and to whom they exported their output.

\section{Private Sector Development}

Privatization is the key to establishing the basis of a market economy, so it is being carried out in Mongolia after carefully analyzing the experience of other countries. In general, the privatization of agricultural, trade and service units is nearly completed, and industrial units are now going through this process. The Mongolian Stock Exchange has been established with local branches all over the country.

It has been estimated that today the private sector accounts for $50 \%$ of the country's GNP, which is evidence that foundations have been laid for the development of the private sector. The difficulties, criticism, resistance as well as red tape still encountered in the privatization process confirm the need for further action. Two key obstacles still remaining are the imperfect understanding of 
private property and the slow progress of actual implementation of adapted policies.

The State Privatization Commission is currently also considering privatizing the more complex sectors. These include public utilities, which require the most regulation as they are often natural monopolies and provide essential products and services. Whether and how to privatize these sectors, and whether to regulate them as private or as state-owned enterprises, are extremely complex issues with which even West European economies still struggle.

As to land ownership, pending the passage of the land law, which will determine the modalities for ownership and transfer of land, legislation will be introduced to establish long-term leasing of agricultural land in the country. In keeping with nomadic tradition, pasture land will likely remain under state ownership but consideration will be given to a system of usage fees based on land value.

In conclusion, a word of warning. The main economic index shows that national income has dropped by $14 \%$ every year since 1990 and now it is only equivalent to the 1983 level. Purchasing power dropped by $42-61 \%$ during the same period, with the first seven months of 1993 showing a decline of $42 \%$. This represents a clear and imminent danger. If Mongolia does not adopt preventive measures immediately, the worsening economic crisis may undermine democratic and economic reforms.

The government and people, therefore, must restore financial stability, keep credit tight, raise more revenues and cut expenditures, ensure a feasible public investment program, and lay a sound basis for future sustainable development. 